\title{
Systematic Review \\ The Value of Platelet-to-Lymphocyte Ratio as a Prognostic Marker in Cholangiocarcinoma: A Systematic Review and Meta-Analysis
}

\author{
Dong Liu ${ }^{1}\left(\mathbb{D}\right.$, Zoltan Czigany ${ }^{1}\left(\mathbb{D}\right.$, Lara R. Heij ${ }^{1,2} \mathbb{D}^{\mathbb{D}}$, Stefan A. W. Bouwense ${ }^{3}$, Ronald van Dam ${ }^{3}(\mathbb{D}$, \\ Sven A. Lang ${ }^{1} \mathbb{D}$, Tom F. Ulmer ${ }^{1}$, Ulf P. Neumann ${ }^{1,3, *}$ and Jan Bednarsch ${ }^{1, *}$
}

1 Department of Surgery and Transplantation, University Hospital RWTH Aachen, 52074 Aachen, Germany; dliu@ukaachen.de (D.L.); zczigany@ukaachen.de (Z.C.); lheij@ukaachen.de (L.R.H.); svlang@ukaachen.de (S.A.L.); fulmer@ukaachen.de (T.F.U.)

2 Institute of Pathology, University Hospital RWTH Aachen, 52074 Aachen, Germany

3 Department of Surgery, Maastricht University Medical Center (MUMC), 6229 HX Maastricht, The Netherlands; stefan.bouwense@mumc.nl (S.A.W.B.); r.van.dam@mumc.nl (R.v.D.)

* Correspondence: uneumann@ukaachen.de (U.P.N.); jbednarsch@ukaachen.de (J.B.)

check for updates

Citation: Liu, D.; Czigany, Z.; Heij, L.R.; Bouwense, S.A.W.; van Dam, R.; Lang, S.A.; Ulmer, T.F.; Neumann, U.P.; Bednarsch, J. The Value of Platelet-to-Lymphocyte Ratio as a Prognostic Marker in Cholangiocarcinoma: A Systematic Review and Meta-Analysis. Cancers 2022, 14, 438. https://doi.org/ $10.3390 /$ cancers 14020438

Academic Editor: Tim Kendall

Received: 15 December 2021

Accepted: 14 January 2022

Published: 16 January 2022

Publisher's Note: MDPI stays neutral with regard to jurisdictional claims in published maps and institutional affiliations.

Copyright: (C) 2022 by the authors. Licensee MDPI, Basel, Switzerland. This article is an open access article distributed under the terms and conditions of the Creative Commons Attribution (CC BY) license (https:// creativecommons.org/licenses/by/ $4.0 /)$.
Simple Summary: Platelet-to-lymphocyte ratio has shown prognostic value in several malignancies; however, its role in cholangiocarcinoma remains to be determined. Therefore, we conducted a systematic review and meta-analysis of the currently available literature. Overall, our analysis revealed that a high platelet-to-lymphocyte ratio before treatment is associated with an impaired long-term oncological outcome. Further, our results indicate that this assumption was not influenced by the used treatment modality (surgical vs. non-surgical), PLR cut-off values, study population age, or sample size of the included studies. Thus, an elevated pretreatment platelet-to-lymphocyte ratio has valid prognostic value for cholangiocarcinoma patients.

\begin{abstract}
The platelet-to-lymphocyte ratio (PLR), an inflammatory parameter, has shown prognostic value in several malignancies. The aim of this meta-analysis was to determine the impact of pretreatment PLR on the oncological outcome in patients with cholangiocarcinoma (CCA). A systematic literature search has been carried out in the PubMed and Google Scholar databases for pertinent papers published between January 2000 and August 2021. Within a random-effects model, the pooled hazard ratio (HR) and 95\% confidence interval (CI) were calculated to investigate the relationships among the PLR, overall survival (OS), and disease-free survival (DFS). Subgroup analysis, sensitivity analysis, and publication bias were also conducted to further evaluate the relationship. A total of 20 articles comprising 5429 patients were included in this meta-analysis. Overall, the pooled outcomes revealed that a high PLR before treatment is associated with impaired OS (HR = 1.14; $95 \% \mathrm{CI}=1.06-1.24 ; p<0.01)$ and DFS (HR $=1.57 ; 95 \% \mathrm{CI}=1.19-2.07 ; p<0.01)$. Subgroup analysis revealed that this association is not influenced by the treatment modality (surgical vs. non-surgical), PLR cut-off values, or sample size of the included studies. An elevated pretreatment PLR is prognostic for the OS and DFS of CCA patients. More high-quality studies are required to investigate the pathophysiological basis of the observation and the prognostic value of the PLR in clinical management as well as for patient selection.
\end{abstract}

Keywords: cholangiocarcinoma (CCA); platelet-to-lymphocyte ratio (PLR); oncological prognosis; systematic review; meta-analysis

\section{Introduction}

Cholangiocarcinoma (CCA) is the second most common primary liver tumor, accounting for 5 to $30 \%$ of all primary liver malignancies. It originates from mutated epithelial cells of the hepatic bile ducts [1,2]. With respect to the anatomical location, CCA can be divided 
into intrahepatic CCA (iCCA) and extrahepatic CCA (eCCA), which are also related to distinct pathophysiology and clinical outcomes $[3,4]$.

The inflammatory response of the host in the tumor microenvironment is known to play a crucial role in cancer growth and progression and is further linked to systemic inflammation [5]. In this context, counts of neutrophils, lymphocytes, and platelets, as well as hypoalbuminemia and high C-reactive protein (CRP) levels have all been used to calculate clinical scores or ratios, such as the Glasgow Prognostic Score (GPS), the plateletto-lymphocyte ratio (PLR), and the neutrophil-to-lymphocyte ratio (NLR), which have shown associations with oncological and surgical outcomes in various solid tumors [6-9]. However, there are conflicting results regarding these preoperative systemic inflammatory parameters in CCA [10-12].

Thrombocytosis is prevalent in patients with solid tumors, indicating an interaction between cancer and platelets [13]. Platelets have been shown to interact directly with tumor cells, releasing substances that aid tumor development, invasion, and angiogenesis and have the ability to protect tumor cells from destruction by natural killer cells $[14,15]$. In numerous solid tumors, for example, breast, lung, colon, gastric, and ovarian cancer, a relationship between thrombocytosis and an impaired oncological outcome has been demonstrated [16]. As low lymphocyte counts may also be associated with shorter oncological survival, the ratio of platelet to lymphocyte (PLR) has been proposed as a prognostic biomarker $[17,18]$. The aim of this systemic review and meta-analysis was, therefore, to elucidate the role of PLR in oncological outcomes in CCA.

\section{Materials and Methods}

\subsection{Literature Search}

This systematic review was registered in the International Prospective Register of Systematic Reviews (PROSPERO) with the ID CRD42021271435 and was conducted in accordance with the PRISMA (Preferred Reporting Items for Systematic Reviews and Meta-analyses) criteria. PubMed and Google Scholar were systematically searched. The following full-text terms were searched: "Lymphocytes" OR "Platelet-to-lymphocyte ratio" AND “Cholangiocarcinoma (CCA)" OR "Biliary tract cancers (BTC)". The Boolean operator "OR" was used to combine all expressions of cases including abbreviation, while "AND" was used to include lymphocytes and PLR in conjunction with CCA in the search. The search period of the electronic database was from January 2000 to October 2021. During the literature search, no proximity operators were used. Two authors (LD and JB) conducted two independent literature searches in this systematic review, both using the same strategy. No additional papers were chosen after the reference list and citation search were completed. There was no search for unpublished literature.

\subsection{Inclusion and Exclusion Criteria}

Studies concerning the prognostic role of the PLR in CCA were the first choice for inclusion. Further criteria for selection included data on overall survival (OS) or disease-free survival (DFS) for evaluation and pre-treatment determination of the PLR. Exclusion criteria were (1) no access to the full text for quality assessment and data extraction; (2) review, case report, comment, or editorial; (3) non-English studies.

\subsection{Statistical Analysis}

The hazard ratio (HR) and its 95\% confidence interval (CI) were used to assess the association between the PLR and the prognosis of CCA. If the relevant data was not directly reported, it was extracted using survival data from Kaplan-Meier curves by Engauge Digitizer version 12.1, as described previously [19]. RevMan version 5.4 (Cochrane Collaboration, London, UK) was used to merge the results of the studies. Statistical heterogeneity between trials was assessed by a Chi-squared test and suggested to be significant when $\mathrm{I}^{2}>50 \%$ and/or $p<0.05$. A fixed-effects model was used when no heterogeneity was detected among studies, while a random-effects model and subgroup 
analysis were preferred when variance existed. Subgroup analysis was conducted to explore and explain the heterogeneity among the results of different studies. To determine the stability of the overall treatment effects, sensitivity analyses were performed. Therefore, we excluded one study at a time to ensure that no single study would be solely responsible for the significance of any result. Funnel plots were performed to evaluate publication bias [20].

\subsection{Quality Assessment of Studies}

The quality of the selected studies was systematically evaluated by 2 reviewers (DL and JB) using the Newcastle-Ottawa scale [21]. The Newcastle-Ottawa scale is composed of three parameters of quality - selection, outcome assessment, and comparability. Each study was subsequently scored from 0 to 9 points, with higher values indicating better quality.

\section{Results}

\subsection{Literature Search}

The process of selecting articles is depicted in the PRISMA diagram below (Figure 1). A total of 310 articles were found initially after searching the two databases. Then, 199 duplicate records were discovered and eliminated. The remaining 111 studies were further vetted for eligibility after the titles and abstracts were reviewed. Ultimately, 20 studies were included in the analysis [22-41].

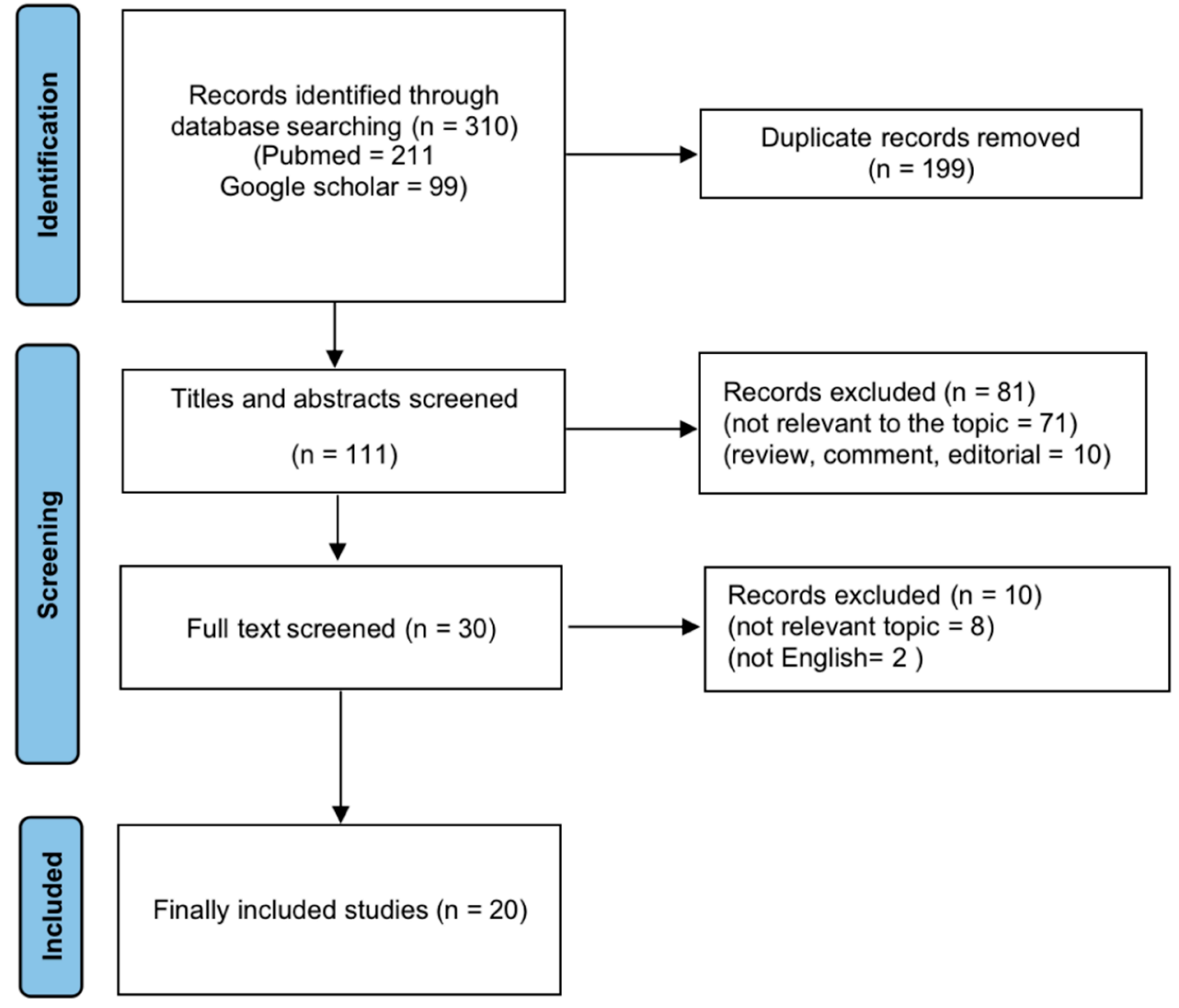

Figure 1. Flowchart of study selection for this study.

\subsection{Study Characteristics and Quality Assessment}

An overview of the included publications is provided in Table 1. All studies were retrospective cohort studies published over the last 6 years. A total of 5429 patients were eligible for analysis, of which 4453 individuals underwent liver resection, while 976 were treated non-surgically. Each study reported survival and the PLR using a variety of approaches. A subset of 12 studies investigated iCCA, 6 studies focused on eCCA, 
and 2 studies comprised both tumor entities. All studies reported a correlation between OS and the PLR, and 8 studies further reported a correlation between DFS and the PLR. The Newcastle-Ottawa scale ranged from 6 to 9, indicating an overall good quality of the methodology of the included studies (Table 2).

Table 1. Characteristics of the 20 eligible studies evaluating PLR in CCA. CCA, cholangiocarcinoma; DFS, disease-free survival; ECCA, extrahepatic cholangiocarcinoma; ICCA, intrahepatic cholangiocarcinoma; NR, not reported; OS, overall survival; PLR, platelet-to-lymphocyte ratio; Ref, reference.

\begin{tabular}{|c|c|c|c|c|c|c|c|c|c|c|c|c|}
\hline Ref & Author & $\begin{array}{c}\text { Year } \\
\text { Published }\end{array}$ & Country & $\begin{array}{l}\text { Tumor } \\
\text { Type }\end{array}$ & $\begin{array}{l}\text { Sample } \\
\text { Size }\end{array}$ & Stage & $\begin{array}{c}\text { Age } \\
\text { (Median) }\end{array}$ & $\begin{array}{c}\text { Male } \\
(\%)\end{array}$ & Treatment & $\begin{array}{l}\text { Follow-Up } \\
\text { (Months, } \\
\text { Median) }\end{array}$ & Endpoin & $\begin{array}{c}\text { Cut-Off } \\
\text { Value }\end{array}$ \\
\hline [22] & Zhao JP & 2021 & China & ICCA & 468 & NR & 58 & $60.30 \%$ & Surgery & NR & OS & $\begin{array}{c}\text { PLR } \geq \\
143.5\end{array}$ \\
\hline [23] & Ma B & 2021 & China & ICCA & 174 & I-IV & 58 & $55.90 \%$ & Surgery & 25.1 & OS/DFS & PLR $\geq 90$ \\
\hline [24] & Zhang ZY & 2020 & China & ICCA & 128 & I-III & 56 & $55.00 \%$ & Surgery & NR & OS/DFS & $\begin{array}{c}\text { PLR } \geq \\
156.8\end{array}$ \\
\hline [25] & $\begin{array}{c}\text { Tsilimigras } \\
\text { DI }\end{array}$ & 2020 & USA & ICCA & 688 & I-III & 57 & $60.50 \%$ & Surgery & 22.3 & OS & $\begin{array}{c}\text { PLR } \geq \\
190\end{array}$ \\
\hline [26] & Ohira M & 2020 & Japan & ICCA & 52 & I-IV & 58 & $78.84 \%$ & Surgery & NR & OS & PLR $\geq 98$ \\
\hline [27] & Ji F & 2020 & China & ECCA & 59 & I-IV & 57 & $55.93 \%$ & Surgery & NR & OS & $\begin{array}{c}\text { PLR } \geq \\
268.9\end{array}$ \\
\hline [28] & Huh G & 2020 & Korea & ICCA & 137 & III-IV & 64 & $60.60 \%$ & $\begin{array}{c}\text { Non- } \\
\text { surgery }\end{array}$ & 9.9 & OS/DFS & $\begin{array}{l}\text { PLR } \geq \\
148\end{array}$ \\
\hline [29] & Wu Y & 2019 & China & $\mathrm{CCA}$ & 119 & NR & 60 & $42.90 \%$ & Surgery & 11 & OS/DFS & $\begin{array}{l}\text { PLR } \geq \\
157.3\end{array}$ \\
\hline [30] & Sellers CM & 2019 & USA & ICCA & 131 & I-IV & 65 & $51.90 \%$ & Surgery & 13 & OS & $\begin{array}{c}\text { PLR } \geq \\
156.4\end{array}$ \\
\hline [31] & Lin J & 2019 & China & ICCA & 218 & I-IV & 60 & $56.90 \%$ & Surgery & NR & OS & $\begin{array}{c}\text { PLR } \geq \\
130.6\end{array}$ \\
\hline [32] & $\mathrm{Hu} \mathrm{HJ}$ & 2019 & China & ECCA & 134 & I-IV & 60 & $63.01 \%$ & Surgery & NR & OS & $\begin{array}{c}\text { PLR } \geq \\
150\end{array}$ \\
\hline [33] & Hoshimoto S & 2019 & Japan & ECCA & 53 & I-IV & 70 & $58.00 \%$ & Surgery & 18 & OS/DFS & $\begin{array}{c}\text { PLR } \geq \\
187.8\end{array}$ \\
\hline [34] & Buettner S & 2018 & Netherlands & ICCA & 991 & I-IV & 59 & $54.10 \%$ & Surgery & 29 & OS & $\begin{array}{c}\text { PLR } \geq \\
190\end{array}$ \\
\hline [35] & Yoh T & 2017 & Japan & ICCA & 141 & I-IV & 65 & $63.00 \%$ & Surgery & NR & OS & $\begin{array}{c}\text { PLR } \geq \\
120\end{array}$ \\
\hline [36] & Kitano Y & 2017 & Japan & ECCA & 120 & I-IV & 58 & $68.33 \%$ & Surgery & NR & OS/DFS & $\begin{array}{c}\text { PLR } \geq \\
185\end{array}$ \\
\hline [37] & Cho H & 2017 & Korea & ICCA & 305 & III-IV & 59 & $61.50 \%$ & $\begin{array}{c}\text { Non- } \\
\text { surgery }\end{array}$ & 25 & OS/DFS & $\begin{array}{c}\text { PLR } \geq \\
128.3\end{array}$ \\
\hline [38] & Saito $\mathrm{H}$ & 2016 & Japan & ECCA & 121 & I-IV & 70 & $72.72 \%$ & Surgery & NR & OS & $\begin{array}{c}\text { PLR } \geq \\
150\end{array}$ \\
\hline [39] & Okuno M & 2016 & Japan & ECCA & 534 & I-IV & 66 & $62.92 \%$ & Surgery & 78 & os & $\begin{array}{c}\text { PLR } \geq \\
150\end{array}$ \\
\hline [40] & $\mathrm{Ha} \mathrm{H}$ & 2016 & Korea & CCA & 534 & III-IV & 60 & $65.20 \%$ & $\begin{array}{l}\text { Non- } \\
\text { surgery }\end{array}$ & 95.3 & OS & $\begin{array}{c}\text { PLR } \geq \\
89.6\end{array}$ \\
\hline [41] & Chen Q & 2015 & China & ICCA & 322 & I-IV & 58 & $60.25 \%$ & Surgery & NR & OS/DFS & $\begin{array}{c}\text { PLR } \geq \\
123\end{array}$ \\
\hline
\end{tabular}

\subsection{Correlation between the PLR and OS of CCA Patients}

Eight studies identified the PLR as an independent predictor for impaired OS in patients with CCA $[22,28,29,33,34,36,38,41]$, while the PLR was not prognostic for OS in twelve studies $[23-27,30-32,35,37,39,40]$. The combined analysis of all twenty publications showed that the PLR values higher than the defined cut-off values predicted a worse OS $(\mathrm{HR}=1.14,95 \% \mathrm{CI}=1.06-1.24, p<0.01)$ with high heterogeneity $\left(\mathrm{I}^{2}=55 \%, p<0.01\right.$, Figure 2). 
Table 2. Quality of included cohort studies evaluated by modified Newcastle-Ottawa scale. The quality of the included studies was assessed under six items of Hayden et al. [21] All included translational studies reporting oncological outcomes were evaluated in accordance with the NewcastleOttawa scale. The maximum score of the scale is nine points, with studies being categorized as low (0-3 points), moderate (4-6 points), or high quality (7-9 points).

\begin{tabular}{|c|c|c|c|c|c|}
\hline Ref. & Author & Selection & Comparability & Outcomes & Quality Score \\
\hline [22] & Zhao JP & 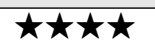 & $\star \star \star$ & $\star \star$ & 9 \\
\hline [23] & Мa B & 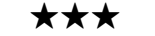 & $\star \star \star$ & $\star \star \star$ & 8 \\
\hline [24] & Zhang ZY & 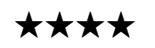 & $\star \star$ & $\star \star$ & 9 \\
\hline [25] & $\begin{array}{c}\text { Tsilimigras } \\
\text { DI }\end{array}$ & 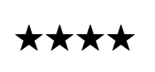 & $\star \star$ & $\star \star$ & 9 \\
\hline [26] & Ohira M & 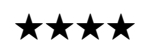 & $\star \star$ & $\star \star \star$ & 9 \\
\hline [27] & Ji F & 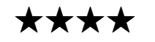 & $\star \star \star$ & $\star \star \star$ & 9 \\
\hline [28] & Huh G & 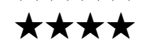 & $\star \star$ & $\star \star$ & 9 \\
\hline [29] & $\mathrm{Wu} \mathrm{Y}$ & 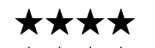 & $\star \star$ & $\star \star$ & 9 \\
\hline [30] & Sellers CM & 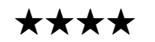 & $\star \star$ & $\star \star$ & 9 \\
\hline [31] & Lin J & 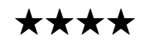 & $\star \star$ & $\star \star$ & 9 \\
\hline [32] & $\mathrm{Hu} \mathrm{HJ}$ & $\star \star \star \star$ & $\star \star \star$ & $\star \star$ & 8 \\
\hline [33] & Hoshimoto S & $\star \star \star \star$ & $\star \star$ & $\star \star$ & 8 \\
\hline [34] & Buettner S & 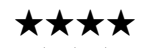 & $\star \star$ & $\star$ & 8 \\
\hline [35] & Yoh T & $\star \star \star \star$ & $\star \star$ & $\star$ & 6 \\
\hline [36] & Kitano Y & 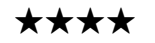 & $\star \star \star$ & $\star \star \star$ & 9 \\
\hline [37] & Cho H & 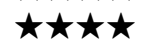 & $\star \star$ & $\star$ & 8 \\
\hline [38] & Saito H & 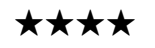 & $\star \star$ & $\star \star$ & 9 \\
\hline [39] & Okuno M & 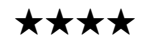 & $\star \star$ & $\star \star$ & 9 \\
\hline [40] & Ha H & 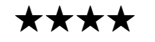 & $\star \star$ & $\star \star \star$ & 9 \\
\hline [41] & Chen Q & 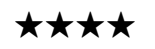 & $\star \star$ & $\star \star$ & 9 \\
\hline
\end{tabular}

Study or Subgroup log[Hazard Ratio] SE Weight IV, Random, 95\% CI

\section{Buettner S 2018}

Chen Q 2015

Cho H 2017

$\mathrm{Ha} \mathrm{H} 2016$

Hoshimoto S 2019

Huh G 2020

Hu HJ 2019

Ji F 2020

Kitano Y 2017

Lin J 2019

Ma B 2021

Ohira M 2020

Okuno M 2016

Saito H 2016

Sellers CM 2019

Tsilimigras DI 2020

Wu Y 2019

Yoh T 2017

Zhang ZY 2020

Zhao JP 2021

$\begin{array}{rrr}0.0388 & 0.0147 & 23.1 \% \\ 0.3437 & 0.1622 & 4.9 \% \\ 0.2159 & 0.2435 & 2.5 \% \\ 0.4571 & 0.2383 & 2.6 \% \\ 0.8048 & 0.3892 & 1.0 \% \\ 0.6188 & 0.1954 & 3.6 \% \\ 0.1058 & 0.1987 & 3.5 \% \\ -0.7791 & 0.4498 & 0.8 \% \\ 0.6243 & 0.2653 & 2.1 \% \\ 0.5112 & 0.3621 & 1.2 \% \\ -0.094 & 0.3527 & 1.2 \% \\ -0.0847 & 0.4682 & 0.7 \% \\ 0.1333 & 0.3202 & 1.5 \% \\ 0.7918 & 0.3109 & 1.6 \% \\ 0.2524 & 0.2688 & 2.1 \% \\ 0.1537 & 0.1614 & 4.9 \% \\ 0.7701 & 0.3265 & 1.4 \% \\ -0.1162 & 0.2579 & 2.2 \% \\ -0.005 & 0.0512 & 17.2 \% \\ 0.0477 & 0.0243 & 21.9 \%\end{array}$

$1.04[1.01,1.07]$

$1.41[1.03,1.94]$

$1.24[0.77,2.00]$

$1.58[0.99,2.52]$

$2.24[1.04,4.80]$

$1.86[1.27,2.72]$

$1.11[0.75,1.64]$

$0.46[0.19,1.11]$

$1.87[1.11,3.14]$

$1.67[0.82,3.39]$

$0.91[0.46,1.82]$

$0.92[0.37,2.30]$

$1.14[0.61,2.14]$

$2.21[1.20,4.06]$

$1.29[0.76,2.18]$

$1.17[0.85,1.60]$

$2.16[1.14,4.10]$

$0.89[0.54,1.48]$

$1.00[0.90,1.10]$

$1.05[1.00,1.10]$

Total $(95 \% \mathrm{Cl})$

$100.0 \%$

$1.14[1.06,1.24]$

Heterogeneity: $\mathrm{Tau}^{2}=0.01 ; \mathrm{Chi}^{2}=42.68, \mathrm{df}=19(\mathrm{P}=0.001) ; \mathrm{I}^{2}=55 \%$

Test for overall effect: $Z=3.32(P=0.0009)$

Hazard Ratio

IV, Random, 95\% CI

Figure 2. Forest plot of the correlation between PLR and OS in CCA patients. A random-effects model was used to estimate the relationship between PLR and OS. OS, overall survival; PLR, plateletto-lymphocyte ratio. 


\subsection{Correlation between the PLR and DFS of CCA Patients}

Five cohort studies showed that the PLR was an independent indicator of poor DFS in patients with CCA $[28,29,31,32,36]$, whereas three publications detected no significant relationship between the PLR and DFS [22,23,36]. The pooled analysis of all eight studies revealed that a higher PLR was associated with worse DFS (HR $=1.57,95 \% \mathrm{CI}=1.19-2.07$, $p<0.01)$ with high heterogeneity $\left(\mathrm{I}^{2}=76 \%, p<0.01\right.$, Figure 3$)$.

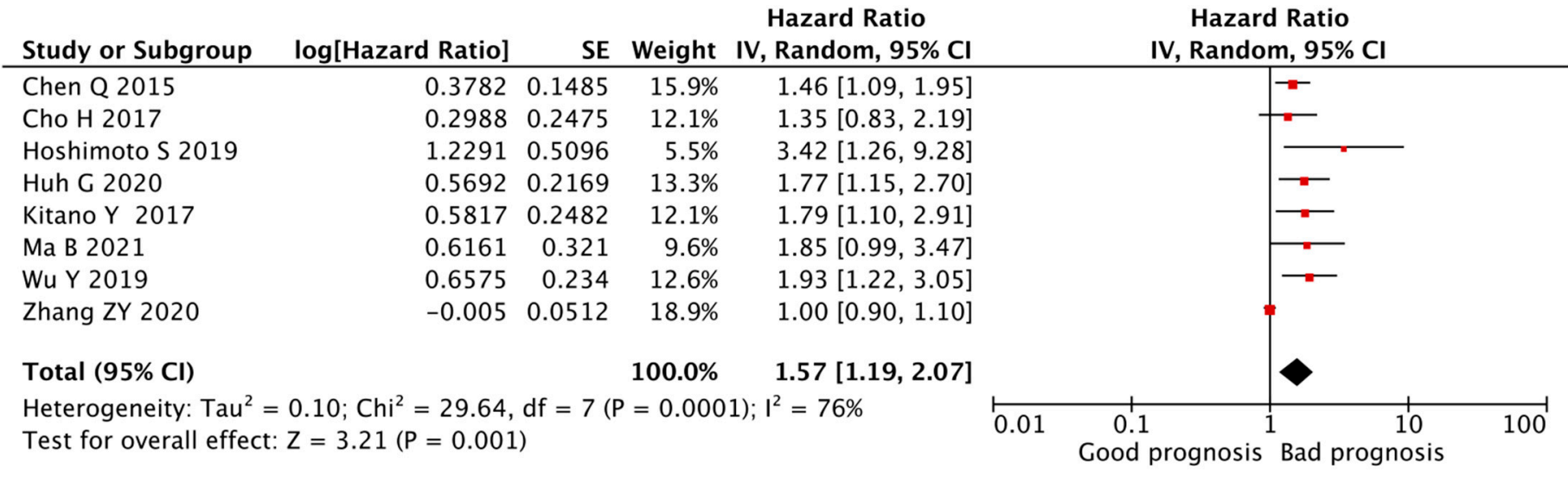

Figure 3. Forest plot of the correlation between PLR and DFS in CCA patients. A random-effects model was used to estimate the relationship between PLR and DFS. DFS, disease-free survival; PLR, platelet-to-lymphocyte ratio.

\subsection{Subgroup Analyses of Correlation between the PLR and OS of CCA Patients}

As stated above, significant heterogeneity was observed in the HR of the OS for the PLR (I2 $=55 \%, p<0.01$, Figure 2 ) and the DFS for the PLR (I2 = 76\%, $p<0.01$, Figure 3 ). Considering the limited number of studies of DFS, we exclusively explored potential causes of the heterogeneity of the OS by subgroup analyses, focusing on cancer type, specific treatment, PLR cut-off values, sample size, and age.

First, we analyzed the significance of a high PLR with respect to OS for patients according to different cancer types, including CCA (combined analysis of iCCA and eCCA), iCCA, and eCCA. While statistical heterogeneity was observed in the eCCA subgroup (I2 $=60 \%, p=0.03$ ), with no significant correlation to OS, heterogeneity was not found in the CCA subgroup (I2 $=0 \%, p=0.44$ ) or the iCCA subgroup (I2 $=35 \%, p=0.12$, Table 3 , Figure S1A).

Between seventeen surgical and three non-surgical studies, the prognostic role of the PLR in OS was unfavorable in both subgroups (surgery group: $\mathrm{HR}=1.09,95 \% \mathrm{CI}=1.02-1.17$, $p=0.02$; non-surgical group: $\mathrm{HR}=1.58,95 \%, \mathrm{CI}=1.23-2.04, p=0.0003$ ). Of note, heterogeneity was not found to be significant in this subgroup analysis (surgery group: $\mathrm{I}^{2}=48 \%$, $p=0.01$; non-surgical group: $\mathrm{I}^{2}=0 \%, p=0.43$, Table 3, Figure S1B).

Because the PLR cut-off values were certainly different among the studies, ranging from 90 to 270, we performed further subgroup analysis based on the PLR cut-off value. In 11 studies with a PLR cut-off greater than 150, and 9 studies with a PLR of less than 150 , the pooled analysis of the PLR with respect to OS was significant in both subgroups (PLR $\geq 150$ group: $\mathrm{HR}=1.17,95 \% \mathrm{CI}=1.02-1.33, p=0.02 ; \mathrm{PLR}<150$ group: $\mathrm{HR}=1.25$, $95 \% \mathrm{CI}=1.03-1.51, p=0.02)$. Statistical heterogeneity was found in the subgroup with a PLR $\geq 150\left(\mathrm{I}^{2}=60 \%, p<0.01\right)$ and in the subgroup with a PLR $<150\left(\mathrm{I}^{2}=53 \%, p=0.03\right.$, Table 3, Figure S1C). 
We further divided the 20 studies into two distinct subgroups according to the sample size ( $\geq 200$ and $<200$ cases). Both groups showed significance regarding the prognostic value of the PLR (sample size $\geq 200$ : $H R=1.07,95 \% \mathrm{CI}=1.01-1.13, p=0.02$; sample size <200: $\mathrm{HR}=1.38,5 \% \mathrm{CI}=1.07-1.77, p=0.01)$. However, statistical heterogeneity was not found in the subgroup with a sample size $\geq 200$ (I2 $=32 \%, p=0.15$ ) but was found in the other corresponding subgroup with a sample size $<200$ (I2 $=69 \%, p=0.01$, Table 3, Figure S1D).

Table 3. Summary of the subgroup analyses of the correlation between the PLR and OS in CCA patients. ${ }^{*}$ Includes both ICCA and ECCA. ${ }^{* *}$ Mean/median age of the study cohort. ECCA, extrahepatic cholangiocarcinoma; ICCA, intrahepatic cholangiocarcinoma; NLR, neutrophil-to-lymphocyte ratio; PLR, platelet-to-lymphocyte ratio.

\begin{tabular}{|c|c|c|c|c|c|}
\hline Subgroup & $\begin{array}{c}\text { Number of } \\
\text { Studies } \\
\end{array}$ & HR (95\% CI) & $p$ Value & $\mathrm{I}^{2}$ & $p$ \\
\hline \multicolumn{6}{|l|}{ Cancer type } \\
\hline $\mathrm{CCA}^{*}$ & 2 & $1.76(1.21-2.57)$ & $<0.01$ & $0 \%$ & 0.44 \\
\hline ICCA & 12 & $1.06(1.00-1.12)$ & 0.03 & $35 \%$ & 0.12 \\
\hline ECCA & 6 & $1.37(0.93-2.03)$ & 0.11 & $60 \%$ & 0.03 \\
\hline \multicolumn{6}{|l|}{ Treatment } \\
\hline Surgery & 17 & 1.09 (1.02-1.17) & 0.02 & $48 \%$ & 0.01 \\
\hline Non-surgery & 3 & $1.58(1.23-2.04)$ & $<0.01$ & $0 \%$ & 0.43 \\
\hline \multicolumn{6}{|l|}{ Cut-off value } \\
\hline PLR $\geq 150$ & 11 & $1.17(1.02-1.33)$ & 0.02 & $60 \%$ & $<0.01$ \\
\hline PLR $<150$ & 9 & $1.25(1.03-1.51)$ & 0.02 & $53 \%$ & 0.03 \\
\hline \multicolumn{6}{|l|}{ Sample size } \\
\hline$\geq 200$ & 10 & 1.07 (1.01-1.13) & 0.02 & $32 \%$ & 0.15 \\
\hline$<200$ & 10 & 1.38 (1.07-1.77) & 0.01 & $69 \%$ & 0.01 \\
\hline \multicolumn{6}{|l|}{ Age ** } \\
\hline$\geq 60$ & 9 & $1.48(1.18-1.85)$ & $<0.01$ & $36 \%$ & 0.13 \\
\hline$<60$ & 11 & $1.06(1.00-1.12)$ & 0.05 & $40 \%$ & 0.08 \\
\hline
\end{tabular}

With respect to age, two groups (median or mean age $\geq 60$ and $<60$ ) were analyzed and showed low heterogeneity ( $\mathrm{I} 2=36 \%, p=0.13$ and $\mathrm{I} 2=40 \%, p=0.08)$. The HRs for the OS for age $\geq 60$ years and for age $<60$ years were $1.48(95 \% \mathrm{CI}=1.18-1.85, p<0.01)$ and $1.06(95 \%$ CI $=1.00-1.12, p=0.05)$, respectively (Table 3, Figure S1E).

\subsection{Sensitivity Analyses of Correlation between the PLR and Prognosis of CCA Patients}

We adopted a random-effects model in the sensitivity analyses, deleting each study in each turn, to further determine the robustness of the prognostic role of the PLR in the DFS and OS of CCA. As shown in Figures 4 and 5, the results of heterogeneity were changed when the studies of Zhang Z.Y. et al. [24] and Huh G. et al. [28] were deleted from the data set. The $\mathrm{I}^{2}$ decreased from 76 to $0 \%$ and 55 to $47 \%$, respectively, but still displayed an unfavorable prognostic effect for DFS (HR $=1.66,95 \% \mathrm{CI}=1.40-1.97, p<0.01)$ and OS $(\mathrm{HR}=1.11,95 \% \mathrm{CI}=1.03-1.19, p<0.01)$. These results indicate a significant contribution of these studies to the high heterogeneity regarding the outcome measures and further support the robustness of the PLR as a prognostic factor of DFS and OS.

\subsection{Publication Bias}

The results from the funnel plot analysis (Figure S2) demonstrated that asymmetry was not present and, therefore, no publication bias affecting the HRs could be displayed. 


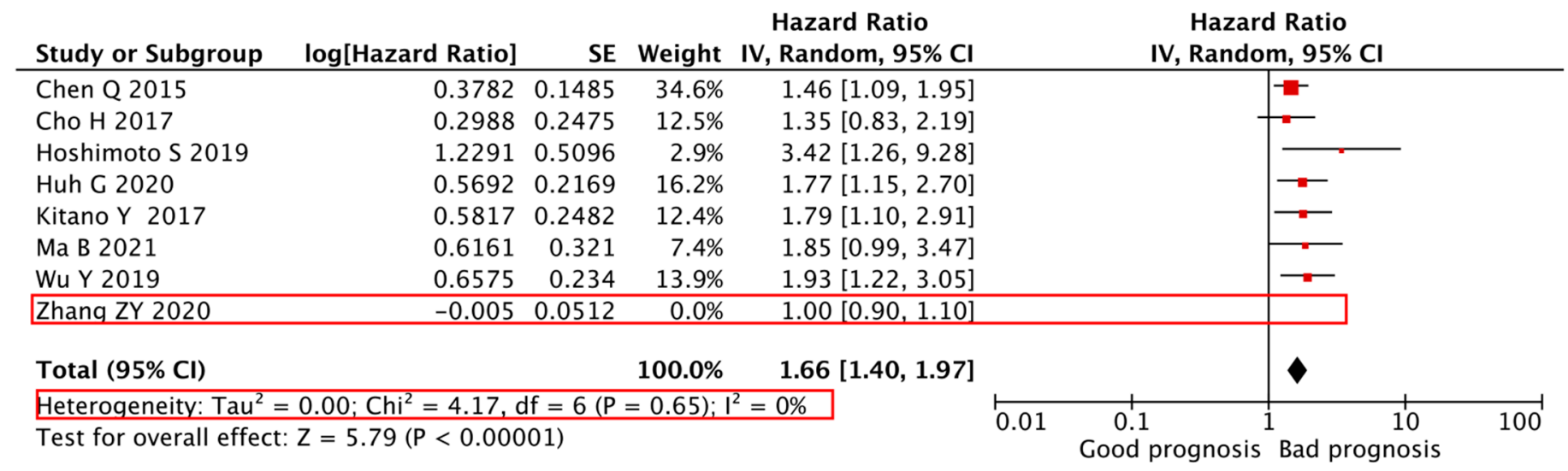

Figure 4. Sensitivity analyses of the association between the PLR and DFS in CCA patients. Sensitivity analyses of the association between the PLR and DFS of 8 studies. A random-effects model was used. DFS, disease-free survival; PLR, platelet-to-lymphocyte ratio.

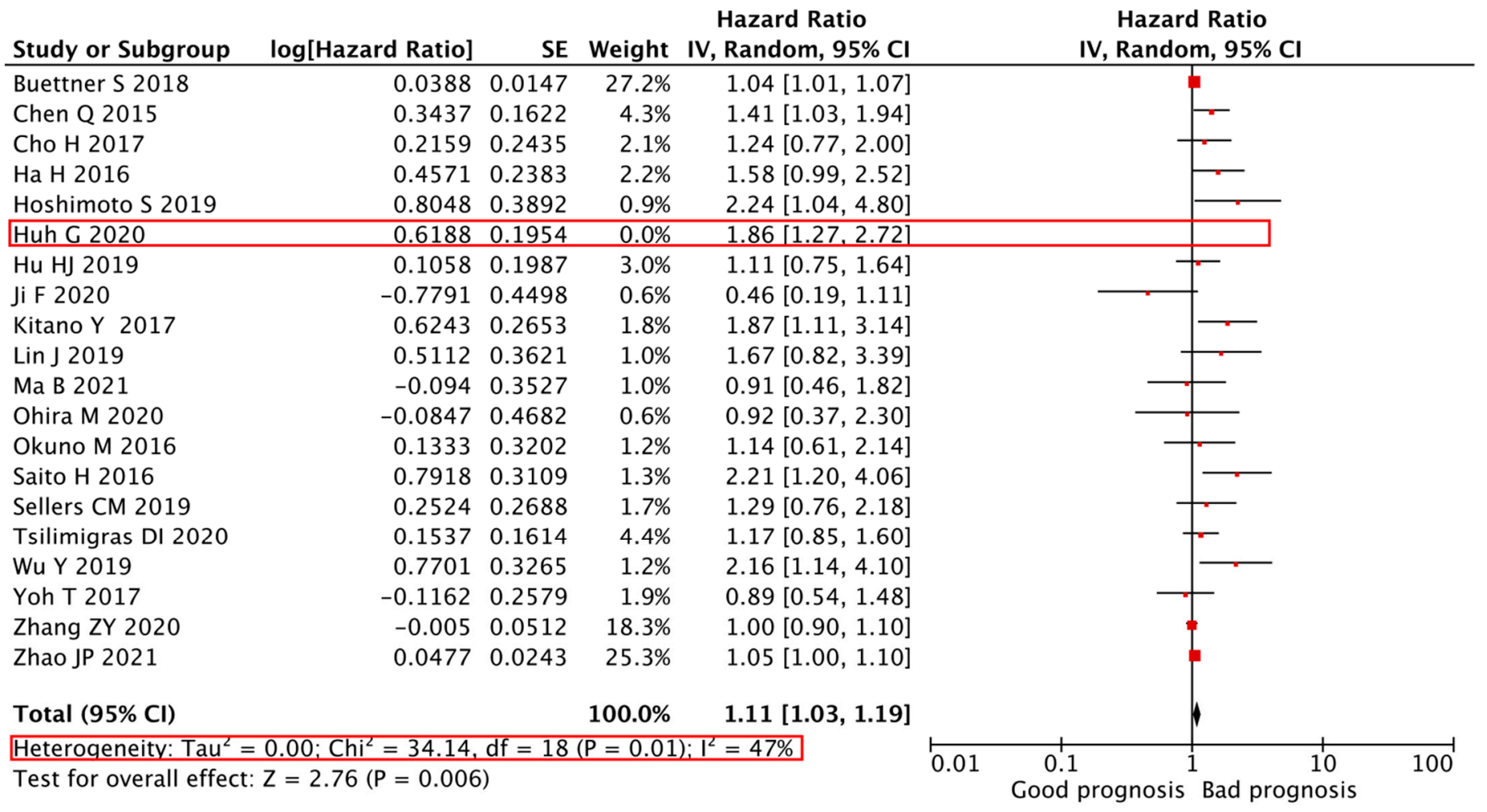

Figure 5. Sensitivity analyses of the association between the PLR and OS in CCA patients. Sensitivity analyses of the association between the PLR and OS of 20 studies. A random-effects model was used. OS, overall survival; PLR, platelet-to-lymphocyte ratio.

\section{Discussion}

According to meta-analyses on several malignancies, including head and neck [42], lung [43], breast [44], renal [45], prostate [46], esophageal [47], pancreatic [48], colorectal [49], and hepatocellular cancers [50], high PLR values are associated with poor oncological survival. In contrast, the PLR has also been shown to be an unreliable prognostic predictor in patients in some other scenarios, for example, gastric cancer [51]. In the present meta-analysis of 20 studies comprising 5429 patients with CCA, we were able to demonstrate that the PLR is of prognostic value in CCA patients. The pooled outcomes revealed that a high pretreatment PLR is associated with impaired OS (HR $=1.14,95 \% \mathrm{CI}=1.06-1.24$, $p<0.01)$ and reduced DFS (HR $=1.57,95 \% \mathrm{CI}=1.19-2.07, p<0.01)$. 
Of note, our subgroup analysis further demonstrated that the unfavorable effect of the PLR is independent from different treatment types, including palliative or curative therapy, the sample size, and the PLR cut-off value, while we observed no statistical significance for patients younger than 60 years. The independence of the prognostic value from the used treatment is particularly interesting, as the genuine oncological outcome of palliative compared to curative treatment is hardly comparable in CCA. While the median OS in the palliative setting is usually less than 12 months with systemic therapy, 5-year survival rates higher than $50 \%$ are reported in distinct subgroups of CCA patients after curativeintent surgical therapy [52-54]. This observation indicates that the PLR could be closely associated with the individual tumor biology and, therefore, could predict the outcome irrespective of the standard of care treatment at each oncological stage. Interestingly, Zheng et al. conducted a similar meta-analysis for hepatocellular carcinoma and also identified a high PLR as an independent risk factor for OS and DFS in HCC patients, both within curative and palliative settings [50].

Further, our subgroup analysis failed to detect a statistically significant association between OS and the PLR in eCCA patients with marginally non-significant values $(\mathrm{HR}=1.37$, $95 \% \mathrm{CI}=0.93-2.03, p=0.11$ ). However, it must be noted that the number of included eCCA studies was limited $(n=6)$ and comprised perihilar as well as distal cholangiocarcinoma, translating to significant heterogeneity $\left(\mathrm{I}^{2}=60 \%, p=0.03\right.$. Figure S1A, Table 3$)$ between the included studies. In addition, eCCA is characterized by a high degree of infectious complications due to recurrent cholangitis, which might be the cause of a dismal long-term outcome $[55,56]$. Considering the primary association of the PLR with oncological survival, it can be assumed that the predictive value of the PLR might be mitigated by the impaired outcome due to septic events.

Chronic inflammation is thought to play a major role in up to $15 \%$ of cancer cases around the world [57]. It is generally known that the systemic inflammatory response plays a key role in carcinogenesis and patient survival. Systemic inflammation is primarily reflected by changes in blood parameters and can be determined by the number of several cell components (neutrophils, lymphocytes, monocytes, and platelets) using standard clinical thresholds [58]. Tumor cells have been demonstrated to excrete platelet-stimulating factors, which promote primary tumor growth, invasion, and metastasis through a variety of pathways [59]. As a result, the platelet count in the peripheral blood is suggested to be an indirect predictor of tumor activity $[60,61]$. Moreover, the presence of antitumor lymphocytes in the peripheral blood, particularly CD8+ T cells, would indicate tumor suppression activity [62]. The ratio of platelets and lymphocytes could, therefore, be an indicator of antitumor activity, prognosis, and/or response to treatment.

However, the detailed mechanism behind the prognostic significance of the PLR in cancer is still unknown. Cancer and inflammatory cells interact reciprocally in experimental studies in terms of extracellular matrix remodeling, angiogenesis, and metastatic preparation [63]. An elevated PLR indicates the activation of transcription factors of an inflammatory response, for example, the signal transducer and activator of transcription 3 (STAT3), hypoxia-inducible factor 1a (HIF1a), and nuclear factor-kB (NF-kB) $[64,65]$. These transcription factors result in the secretion of pro-inflammatory cytokines that also promote tumor growth, such as TNF-a, IL-1 $\beta$, and IL-6 [66,67]. In addition, cancer-related inflammation plays a role in epithelial-mesenchymal transition (EMT), angiogenesis, cell proliferation and survival, tumor-cell migration, invasion, and metastasis, as well as treatment response [63]. NF- $\kappa B$ was found to be overexpressed in CCA tissues and the inhibition of NF- $\mathrm{BB}$ action significantly enhanced cell apoptosis and reduced cell growth, which suggests NF- $\kappa$ B as a potential molecular target for CCA therapy [68]. Yang et al. observed that STAT3 overexpression promotes metastasis in iCCA and correlates negatively with surgical outcomes [69]. In addition, Yu et al. found that HIF1a could activate the lncRNA H19-mediated miR-612/Bcl-2 pathway to promote cholangiocarcinoma [70]. An elevated PLR might, therefore, also be a surrogate for the activity of transcription factors associated with cancer progression in CCA. This is also supported by an increasing number of studies 
focusing on the relationship between the PLR and tumor characteristics. For example, in cervical cancer and colorectal cancer, a higher PLR was associated with a higher rate of lymph node metastasis [71,72].

It is well known that escaping from immune surveillance is a hallmark feature of tumorigenesis and cancer progression. Recently, immunotherapy, for example, immune checkpoint inhibitors (ICIs), chimeric antigen receptor (CAR) T-cells, and tumor vaccines emerged as novel treatment modalities for malignancies [73]. However, the response rates to immunotherapy are quite different in CCA compared to other solid tumors due to the spatial heterogeneity of biliary tract cancer itself [74]. In fact, there is a lack of reliable predictive biomarkers, which is a main obstacle in the use of immunotherapies in CCA [75]. Thus, the identification of such biomarkers identifying subgroups would facilitate clinical management in CCA significantly.

A recent meta-analysis of 1845 patients with non-small cell lung cancer (NSCLC) comprising 21 studies that included treatment with three ICIs found that a high PLR was associated with poor OS and PFS [76]. Another meta-analysis from $\mathrm{Xu}$ et al. evaluated 12 trials including 1430 cancer patients and observed the detrimental impact a high PLR had on the efficacy of ICIs (HR for OS = 2.0) [77]. Diem et al. also reported that an elevated PLR was associated with shorter OS and PFS and lower response rates in NSCLC patients treated with nivolumab [78]. Hence, the PLR might serve as an easily accessible prognostic marker for the response to immunotherapy. Nevertheless, Zer et al. detected no significant link between the baseline PLR and immunotherapy efficacy in CCA. Therefore, more studies are required to evaluate the PLR as a predictive biomarker for monitoring therapy success [79].

As with all meta-analyses with limited available literature, our study has certain limitations. All included studies were retrospective analyses in nature, leaving a potential selection bias in the published data. In addition, a variety of methodologies was used and, most importantly, different PLR cut-off levels. These different cut-offs impede the routine application of the parameter in clinical management and warrant further research. As some studies did not report HRs and CIs in detail, these variables had to be extrapolated from the survival curves in four studies [24-31,37,39]. Further, the available data were unfortunately not sufficient to investigate the association between the PLR and tumor clinicopathological characteristics.

\section{Conclusions}

In light of the above, we were able to demonstrate that an elevated pretreatment PLR is predictive for the prognosis of CCA patients. Large-scale prospective cohort studies are warranted to confirm the independent prognostic effect of the PLR on CCA.

Supplementary Materials: The following are available online at https:/ /www.mdpi.com/article/ 10.3390/ cancers14020438/s1, Figure S1: Stratified forest plots of the association between the PLR and OS in CCA patients. Figure S2: Funnel plot of the meta-analysis of PLR in OS (A) and DFS (B).

Author Contributions: Conceptualization, D.L. and J.B.; methodology, D.L., U.P.N. and J.B.; formal analysis, D.L., Z.C., L.R.H., T.F.U. and J.B.; investigation, D.L., S.A.W.B., R.v.D., S.A.L. and J.B.; resources, U.P.N.; data curation, Z.C., S.A.L. and J.B.; writing-original draft preparation, D.L., L.R.H., S.A.W.B., R.v.D. and J.B.; writing-review and editing, Z.C., S.A.L., T.F.U. and U.P.N.; supervision, U.P.N.; project administration, UPN. All authors have read and agreed to the published version of the manuscript.

Funding: This research was supported by DFG (German Research Foundation)_Project-ID 403224013SFB 1382.

Data Availability Statement: The data presented in this study are available upon request from the corresponding author.

Conflicts of Interest: The authors declare no conflict of interest. 


\section{References}

1. Oliveira, I.S.; Kilcoyne, A.; Everett, J.M.; Mino-Kenudson, M.; Harisinghani, M.G.; Ganesan, K. Cholangiocarcinoma: Classification, diagnosis, staging, imaging features, and management. Abdom Radiol. 2017, 42, 1637-1649. [CrossRef]

2. Ghouri, Y.A.; Mian, I.; Blechacz, B. Cancer review: Cholangiocarcinoma. J. Carcinog. 2015, 14, 1.

3. Banales, J.M.; Cardinale, V.; Carpino, G.; Marzioni, M.; Andersen, J.B.; Invernizzi, P.; Lind, G.E.; Folseraas, T.; Forbes, S.J.; Fouassier, L.; et al. Expert consensus document: Cholangiocarcinoma: Current knowledge and future perspectives consensus statement from the European Network for the Study of Cholangiocarcinoma (ENS-CCA). Nat. Rev. Gastroenterol. Hepatol. 2016, 13, 261-280. [CrossRef]

4. $\quad$ Bednarsch, J.; Czigany, Z.; Heij, L.R.; Luedde, T.; Loosen, S.H.; Dulk, M.D.; Bruners, P.; Lang, S.A.; Ulmer, T.F.; Neumann, U.P. The prognostic role of in-hospital transfusion of fresh frozen plasma in patients with cholangiocarcinoma undergoing curative-intent liver surgery. Eur. J. Surg. Oncol. 2021. [CrossRef]

5. Templeton, A.J.; McNamara, M.G.; Seruga, B.; Vera-Badillo, F.E.; Aneja, P.; Ocana, A.; Leibowitz, A.R.; Sonpavde, G.; Knox, J.J.; Tran, B.; et al. Prognostic role of neutrophil-to-lymphocyte ratio in solid tumors: A systematic review and meta-analysis. J. Natl. Cancer Inst. 2014, 106, dju124. [CrossRef]

6. Templeton, A.J.; Ace, O.; McNamara, M.G.; Al-Mubarak, M.; Vera-Badillo, F.E.; Hermanns, T.; Seruga, B.; Ocana, A.; Tannock, I.F.; Amir, E. Prognostic role of platelet to lymphocyte ratio in solid tumors: A systematic review and meta-analysis. Cancer Epidemiol. Biomarkers Prev. 2014, 23, 1204-1212. [CrossRef]

7. McMillan, D.C. The systemic inflammation-based Glasgow Prognostic Score: A decade of experience in patients with cancer. Cancer Treat. Rev. 2013, 39, 534-540. [CrossRef] [PubMed]

8. Amygdalos, I.; Bednarsch, J.; Meister, F.A.; Erren, D.; Mantas, A.; Strnad, P.; Lang, S.A.; Ulmer, T.F.; Boecke, J.; Liu, W.; et al. Clinical value and limitations of the preoperative C-reactive-protein-to-albumin ratio in predicting post-operative morbidity and mortality after deceased-donor liver transplantation: A retrospective single-centre study. Transpl. Int. 2021, 34, 1468-1480. [CrossRef] [PubMed]

9. Radulescu, D.; Baleanu, V.D.; Padureanu, V.; Radulescu, P.M.; Bordu, S.; Patrascu, S.; Socea, B.; Bacalbase, N.; Surlin, M.V.; Georgescu, I.; et al. Neutrophil/Lymphocyte ratio as predictor of anastomotic leak after gastric cancer surgery. Diagnostics 2020, 10, 799. [CrossRef] [PubMed]

10. Hakeem, A.R.; Marangoni, G.; Chapman, S.J.; Young, R.S.; Nair, A.; Hidalgo, E.L.; Toogood, G.J.; Wyatt, J.I.; Lodge, P.A.; Prasad, K.R. Does the extent of lymphadenectomy, number of lymph nodes, positive lymph node ratio and neutrophillymphocyte ratio impact surgical outcome of perihilar cholangiocarcinoma? Eur. J. Gastroenterol. Hepatol. 2014, 26, 1047-1054. [CrossRef]

11. Hamed, M.O.; Roberts, K.J.; Smith, A.M.; Stiff, G.M. Elevated pre-operative neutrophil to lymphocyte ratio predicts disease free survival following pancreatic resection for periampullary carcinomas. Pancreatology 2013, 13, 534-538. [CrossRef]

12. Tan, D.W.; Fu, Y.; Su, Q.; Guan, M.J.; Kong, P.; Wang, S.Q.; Wang, H.L. Prognostic significance of neutrophil to lymphocyte ratio in oncologic outcomes of cholangiocarcinoma: A meta-analysis. Sci. Rep. 2016, 6, 1-6. [CrossRef] [PubMed]

13. Wagner, D.D. New links between inflammation and thrombosis. Arterioscl. Throm. Vas. 2005, 25, 1321-1324. [CrossRef] [PubMed]

14. Jain, S.; Harris, J.; Ware, J. Platelets linking hemostasis and cancer. Arterioscl. Throm. Vas. 2010, 30, 2362-2367. [CrossRef] [PubMed]

15. Nieswandt, B.; Hafner, M.; Echtenacher, B.; Mannel, D.N. Lysis of tumor cells by natural killer cells in mice is impeded by platelets. Cancer Res. 1999, 59, 1295-1300.

16. Buergy, D.; Wenz, F.; Groden, C.; Brockmann, M.A. Tumor-platelet interaction in solid tumors. Int. J. Cancer. 2012, 130, 2747-2760. [CrossRef] [PubMed]

17. Vigano, A.; Bruera, E.; Jhangri, G.S.; Newman, S.C.; Fields, A.L.; Suarez-Almazor, M.E. Clinical survival predictors in patients with advanced cancer. Arch. Intern. Med. 2000, 160, 861-868. [CrossRef] [PubMed]

18. Amygdalos, I.; Czigany, Z.; Bednarsch, J.; Boecker, J.; Santana, D.A.M.; Meister, F.A.; Von der Massen, J.; Liu, W.J.; Strnad, P.; Neumann, U.P.; et al. Low postoperative platelet counts are associated with major morbidity and inferior survival in adult recipients of orthotopic liver transplantation. J. Gastrointest. Surg. 2020, 24, 1996-2007. [CrossRef] [PubMed]

19. Tierney, J.F.; Stewart, L.A.; Ghersi, D.; Burdett, S.; Sydes, M.R. Practical methods for incorporating summary time-to-event data into meta-analysis. Trials 2007, 8, 1-16. [CrossRef]

20. Galon, J.; Pages, F.; Marincola, F.M.; Angell, H.K.; Thurin, M.; Lugli, A.; Zlobec, C.; Botti, G.; Kreiter, S.; Chouchane, L.; et al. Cancer classification using the Immunoscore: A worldwide task force. J. Trans. Med. 2012, 10, 1-10. [CrossRef]

21. Wells, G.S.B.; O'Connell, D.; Peterson, J.; Welch, V.; Losos, M. The Newcastleottawa Scale (NOS) for Assessing the Quality if Non-Randomized Studies in Meta-Analyses. Available online: http://www.ohri.ca/programs/clinical_epidemiology/oxford.asp (accessed on 14 December 2021).

22. Zhao, J.P.; Chen, Y.; Wang, J.J.; Wang, J.; Wang, Y.; Chai, S.S.; Zhang, Y.X.; Chen, X.P.; Zhang, W.U. Preoperative risk grade predicts the long-term prognosis of intrahepatic cholangiocarcinoma: A retrospective cohort analysis. BMC Surg. 2021, 21, 1-11. [CrossRef] [PubMed]

23. Ma, B.; Meng, H.; Shen, A.; Ma, Y.; Zhao, D.; Liu, G.; Zheng, S.; Tian, Y.; Zhang, W.; Li, Q.; et al. Prognostic value of inflammatory and tumour markers in small-duct subtype intrahepatic cholangiocarcinoma after curative-intent resection. Gastroenterol. Res. Pract. 2021, 2021, 6616062. [CrossRef] [PubMed] 
24. Zhang, Z.Y.; Zhou, Y.F.; Hu, K.; Huang, Y. Investigating effects of preoperative inflammatory biomarkers on predicting survival outcomes of intrahepatic cholangiocarcinoma after curative resection. World J. Surg. Oncol. 2020, 18, 1-7. [CrossRef]

25. Tsilimigras, D.I.; Moris, D.; Mehta, R.; Paredes, A.Z.; Sahara, K.; Guglielmi, A.; Aldrighetti, L.; Weiss, M.; Bauer, T.W.; Alexandrescu, S.; et al. The systemic immune-inflammation index predicts prognosis in intrahepatic cholangiocarcinoma: An international multi-institutional analysis. HPB 2020, 22, 1667-1674. [CrossRef]

26. Ohira, M.; Yoshizumi, T.; Yugawa, K.; Kosai-Fujimoto, Y.; Inokuchi, S.; Motomura, T.; Mano, Y.; Toshima, T.; Itoh, S.; Harada, Y.; et al. Association of inflammatory biomarkers with long-term outcomes after curative surgery for mass-forming intrahepatic cholangiocarcinoma. Surg. Today 2020, 50, 379-388. [CrossRef]

27. Ji, F.; Kang, Q.; Wang, L.; Liu, L.; Ke, Y.; Zhu, Y.; Zhang, N.; Xiong, S.; Li, Y.; Zou, H. Prognostic significance of the neutrophil-tolymphocyte ratio with distal cholangiocarcinoma patients. Medicine 2020, 99, e22827. [CrossRef]

28. Huh, G.; Ryu, J.K.; Chun, J.W.; Kim, J.S.; Park, N.; Cho, I.R.; Paik, W.H.; Lee, S.H.; Kim, Y.T. High platelet-to-lymphocyte ratio is associated with poor prognosis in patients with unresectable intrahepatic cholangiocarcinoma receiving gemcitabine plus cisplatin. BMC Cancer 2020, 20, 1-13. [CrossRef]

29. Wu, Y.; Zhou, D.Y.; Zhang, G.P.; Yi, F.M.; Feng, L. Preoperative serum platelet-lymphocyte ratio as a prognostic factor in cholangiocarcinoma patients after radical resection: A retrospective analysis of 119 patients. Gastroent. Res. Pract. 2019. [CrossRef]

30. Sellers, C.M.; Uhlig, J.; Ludwig, J.M.; Stein, S.M.; Kim, H.S. Inflammatory markers in intrahepatic cholangiocarcinoma: Effects of advanced liver disease. Cancer Med. 2019, 8, 5916-5929. [CrossRef]

31. Lin, J.; Fang, T.; Zhu, M.; Xu, X.; Zhang, J.; Zheng, S.; Jing, C.; Zhang, M.; Liu, B.; Zhang, B. Comparative performance of inflammation-based prognostic scores in patients operated for intrahepatic cholangiocarcinoma. Cancer Manag. Res. 2019, 11, 9107-9119. [CrossRef] [PubMed]

32. Hu, H.J.; Jin, Y.W.; Zhou, R.X.; Ma, W.J.; Yang, Q.; Wang, J.K.; Liu, F.; Cheng, N.S.; Li, F.Y. Clinical value of inflammation-based prognostic scores to predict the resectability of hyperbilirubinemia patients with potentially resectable hilar cholangiocarcinoma. J. Gastrointest. Surg. 2019, 23, 510-517. [CrossRef]

33. Hoshimoto, S.; Hishinuma, S.; Shirakawa, H.; Tomikawa, M.; Ozawa, I.; Ogata, Y. Association of preoperative platelet-tolymphocyte ratio with poor outcome in patients with distal cholangiocarcinoma. Oncology 2019, 96, 290-298. [CrossRef]

34. Buettner, S.; Spolverato, G.; Kimbrough, C.W.; Alexandrescu, S.; Marques, H.P.; Lamelas, J.; Aldrighetti, L.; Gamblin, T.C.; Maithel, S.K.; Pulitano, C.; et al. The impact of neutrophil-to-lymphocyte ratio and platelet-to-lymphocyte ratio among patients with intrahepatic cholangiocarcinoma. Surgery 2018, 164, 411-418. [CrossRef] [PubMed]

35. Yoh, T.; Seo, S.; Hatano, E.; Taura, K.; Fuji, H.; Ikeno, Y.; Okuda, Y.; Yasuchika, K.; Kaido, T.; Okajina, H.; et al. A novel biomarkerbased preoperative prognostic grading system for predicting survival after surgery for intrahepatic cholangiocarcinoma. Ann. Surg. Oncol. 2017, 24, 1351-1357. [CrossRef]

36. Kitano, Y.; Yamashita, Y.I.; Yamamura, K.; Arima, K.; Kaida, T.; Miyata, T.; Nakagawa, S.; Mima, K.; Imai, K.; Hashimoto, D.; et al Effects of preoperative neutrophil-to-lymphocyte and platelet-to-lymphocyte ratios on survival in patients with extrahepatic cholangiocarcinoma. Anticancer Res. 2017, 37, 3229-3237.

37. Cho, H.; Yoo, C.; Kim, K.P.; Chang, H.M.; Ryoo, B.Y. Prognostic implication of inflammation-based prognostic scores in patients with intrahepatic cholangiocarcinoma (iCCA) treated with first-line gemcitabine plus cisplatin (GEMCIS). Ann. Oncol. 2017, 28, v244. [CrossRef]

38. Saito, H.; Noji, T.; Okamura, K.; Tsuchikawa, T.; Shichinohe, T.; Hirano, S. A new prognostic scoring system using factors available preoperatively to predict survival after operative resection of perihilar cholangiocarcinoma. Surgery 2016, 159, 842-851. [CrossRef]

39. Okuno, M.; Ebata, T.; Yokoyama, Y.; Igami, T.; Sugawara, G.; Mizuno, T.; Yamaguchi, J.; Nagino, M. Evaluation of inflammationbased prognostic scores in patients undergoing hepatobiliary resection for perihilar cholangiocarcinoma. J. Gastroenterol. 2016, 51, 153-161. [CrossRef] [PubMed]

40. Ha, H.; Nam, A.R.; Bang, J.H.; Park, J.E.; Kim, T.Y.; Lee, K.H.; Han, S.W.; Lm, S.A.; Kim, T.Y.; Bang, Y.J.; et al. Soluble programmed death-ligand 1 (sPDL1) and neutrophil-to-lymphocyte ratio (NLR) predicts survival in advanced biliary tract cancer patients treated with palliative chemotherapy. Oncotarget 2016, 7, 76604-76612. [CrossRef] [PubMed]

41. Chen, Q.; Dai, Z.; Yin, D.; Yang, L.X.; Wang, Z.; Xiao, Y.S.; Fan, J.; Zhou, J. Negative impact of preoperative platelet-lymphocyte ratio on outcome after hepatic resection for intrahepatic cholangiocarcinoma. Medicine 2015, 94, e574. [CrossRef] [PubMed]

42. Yang, L.; Huang, Y.; Zhou, L.; Dai, Y.H.; Hu, G.Y. High pretreatment neutrophil-to-lymphocyte ratio as a predictor of poor survival prognosis in head and neck squamous cell carcinoma: Systematic review and meta-analysis. Head Neck J. Sci. Spec. 2019, 41, 1525-1535. [CrossRef]

43. Peng, B.; Wang, Y.H.; Liu, Y.M.; Ma, L.X. Prognostic significance of the neutrophil to lymphocyte ratio in patients with non-small cell lung cancer: A systemic review and meta-analysis. Int. J. Clin. Exp. Med. 2015, 8, 3098-3106. [PubMed]

44. Koh, C.H.; Bhoo-Pathy, N.; Ng, K.L.; Jabir, R.S.; Tan, G.H.; See, M.H.; Jamaris, S.; Taib, N.A. Utility of pre-treatment neutrophillymphocyte ratio and platelet-lymphocyte ratio as prognostic factors in breast cancer. Brit. J. Cancer. 2015, 113, 150-158. [CrossRef]

45. Hu, K.M.; Lou, L.X.; Ye, J.; Zhang, S.Z. Prognostic role of the neutrophil-lymphocyte ratio in renal cell carcinoma: A meta-analysis. BMJ Open 2015, 5, e006404. [CrossRef] [PubMed] 
46. Guo, J.; Fang, J.; Huang, X.; Liu, Y.; Yuan, Y.; Zhang, X.; Zou, C.; Xiao, K.; Wang, J. Prognostic role of neutrophil to lymphocyte ratio and platelet to lymphocyte ratio in prostate cancer: A meta-analysis of results from multivariate analysis. Int. J. Surg. 2018, 60, 216-223. [CrossRef]

47. Yodying, H.; Matsuda, A.; Miyashita, M.; Matsumoto, S.; Sakurazawa, N.; Yamada, M.; Uchida, E. Prognostic significance of neutrophil-to-lymphocyte ratio and platelet-to-lymphocyte ratio in oncologic outcomes of esophageal cancer: A systematic review and meta-analysis. Ann. Surg. Oncol. 2016, 23, 646-654. [CrossRef] [PubMed]

48. Oh, D.; Pyo, J.S.; Son, B.K. Prognostic roles of inflammatory markers in pancreatic cancer: Comparison between the neutrophil-tolymphocyte ratio and platelet-to-lymphocyte ratio. Gastroent. Res. Pract. 2018, 25, 169-178. [CrossRef]

49. Zhang, J.; Zhang, H.Y.; Li, J.; Shao, X.Y.; Zhang, C.X. The elevated NLR, PLR and PLT may predict the prognosis of patients with colorectal cancer: A systematic review and meta-analysis. Oncotarget 2017, 8, 68837-68846. [CrossRef] [PubMed]

50. Zheng, J.; Cai, J.Y.; Li, H.; Zeng, K.N.; He, L.Y.; Fu, H.Y.; Zhang, J.B.; Chen, L.; Yao, J.; Zhang, Y.C.; et al. Neutrophil to lymphocyte ratio and platelet to lymphocyte ratio as prognostic predictors for hepatocellular carcinoma patients with various treatments: A meta-analysis and systematic review. Cell. Physiol. Biochem. 2017, 44, 967-981. [CrossRef] [PubMed]

51. Xu, Z.S.; Xu, W.; Cheng, H.; Shen, W.; Ying, J.Q.; Cheng, F.; Xu, W.J. The prognostic role of the platelet-lymphocytes ratio in gastric cancer: A meta-analysis. PLoS ONE 2016, 11, e0163719. [CrossRef] [PubMed]

52. Valle, J.; Wasan, H.; Palmer, D.H.; Cunningham, D.; Anthoney, A.; Maraveyas, A.; Madhusudan, S.; Iveson, T.; Hughes, S.; Pereira, S.P.; et al. Cisplatin plus gemcitabine versus gemcitabine for biliary tract cancer. N. Engl. J. Med. 2010, 362, 1273-1281. [CrossRef]

53. Bednarsch, J.; Kather, J.; Tan, X.; Sivakumar, S.; Cacchi, C.; Wiltberger, G.; Czigany, Z.; Ulmer, F.; Neumann, U.P.; Heij, L.R. Nerve fibers in the tumor microenvironment as a novel biomarker for oncological outcome in patients undergoing surgery for perihilar cholangiocarcinoma. Liver Cancer 2021, 10, 260-274. [CrossRef]

54. Bednarsch, J.; Czigany, Z.; Heij, L.R.; Luedde, T.; Wiltberger, G.; Dulk, M.D.; Bruners, P.; Lang, S.A.; Ulmer, T.F.; Neumann, U.P. The prognostic role of tumor-associated unilateral portal vein occlusion in perihilar cholangiocarcinoma. HPB 2021, 23, 1565-1577. [CrossRef]

55. Bednarsch, J.; Czigany, Z.; Lurje, I.; Amygdalos, I.; Strnad, P.; Halm, P.; Wiltberger, G.; Ulmer, T.F.; Schulze-Hagen, M.; Bruners, P.; et al. Insufficient future liver remnant and preoperative cholangitis predict perioperative outcome in perihilar cholangiocarcinoma. HPB 2021, 23, 99-108. [CrossRef]

56. Bednarsch, J.; Czigany, Z.; Heij, L.R.; Luedde, T.; van Dam, R.; Lang, S.A.; Ulmer, T.F.; Hornel, M.W.; Neumann, U.P. Bacterial bile duct colonization in perihilar cholangiocarcinoma and its clinical significance. Sci. Rep. 2021, 11, 2926. [CrossRef] [PubMed]

57. Ulich, T.R.; del Castillo, J.; Keys, M.; Granger, G.A.; Ni, R.X. Kinetics and mechanisms of recombinant human interleukin 1 and tumor necrosis factor-alpha-induced changes in circulating numbers of neutrophils and lymphocytes. J. Immunol. 1987, 139, 3406-3415. [PubMed]

58. Riesco, A. Five-year cancer cure: Relation to total amount of peripheral lymphocytes and neutrophils. Cancer 1970, 25, 135-140. [CrossRef]

59. Plantureux, L.; Mege, D.; Crescence, L.; Dignat-George, F.; Dubois, C.; Panicot-Dubois, L. Impacts of cancer on platelet production, activation and education and mechanisms of cancer-associated thrombosis. Cancers 2018, 10, 441. [CrossRef]

60. Krenn-Pilko, S.; Langsenlehner, U.; Thurner, E.M.; Stojakovic, T.; Pichler, M.; Gerger, A.; Kapp, K.S.; Langsenlehner, T. The elevated preoperative platelet-to-lymphocyte ratio predicts poor prognosis in breast cancer patients. Brit. J. Cancer 2014, 110, 2524-2530. [CrossRef]

61. Seretis, C.; Seretis, F.; Lagoudianakis, E.; Politou, M.; Gemenetzis, G.; Salemis, N.S. Enhancing the accuracy of platelet to lymphocyte ratio after adjustment for large platelet count: A pilot study in breast cancer patients. Int. J. Surg. Oncol. 2012, 2012, 653608. [CrossRef]

62. Yu, P.; Fu, Y.X. Tumor-infiltrating T lymphocytes: Friends or foes? Lab. Investig. 2006, 86, 231-245. [CrossRef] [PubMed]

63. Mantovani, A.; Allavena, P.; Sica, A.; Balkwill, F. Cancer-related inflammation. Nature 2008, 454, 436-444. [CrossRef]

64. Eli Pikarsky, R.M.P.; Stein, I.; Abramovitch, R.; Amit, S.; Kasem, S.; Gutkovich-Pyest, E.; Urieli-Shoval, S.; Galun, E.; Ben-Neriah, Y. NF-kappaB functions as a tumour promoter in inflammation-associated cancer. Nature 2004, 431, 461-466. [CrossRef]

65. Jordi Rius, M.G.; Schachtrup, C.; Akassoglou, K.; Zinkernagel, A.S.; Nizet, V.; Johnson, R.S.; Haddad, G.G.; Karin, M. NF-kappaB links innate immunity to the hypoxic response through transcriptional regulation of HIF-1alpha. Nature 2008, 453, 807-811. [CrossRef] [PubMed]

66. Mizukami, Y.; Jo, W.S.; Duerr, E.M.; Gala, M.; Li, J.; Zhang, X.; Zimmer, M.A.; Lliopoulos, O.; Zukerberg, L.R.; Kohgo, Y.; et al. Induction of interleukin-8 preserves the angiogenic response in HIF-1alpha-deficient colon cancer cells. Nat. Med. 2005, 11, 992-997. [CrossRef]

67. Szlosarek, P.W.; Balkwill, F.R. Tumour necrosis factor alpha: A potential target for the therapy of solid tumours. Lancet Oncol. 2003, 4, 565-573. [CrossRef]

68. Seubwai, W.; Wongkham, C.; Puapairoj, A.; Khuntikeo, N.; Pugkhem, A.; Hahnvajanawong, C.; Chaiyagoo, J.; Ymezawa, K.; Okada, S.; Wongkham, S. Aberrant expression of NF-kappaB in liver fluke associated cholangiocarcinoma: Implications for targeted therapy. PLoS ONE 2014, 9, e106056. [CrossRef]

69. Yang, X.W.; Li, L.; Hou, G.J.; Yan, X.Z.; Xu, Q.G.; Chen, L.; Zhang, B.H.; Shen, F. STAT3 overexpression promotes metastasis in intrahepatic cholangiocarcinoma and correlates negatively with surgical outcome. Oncotarget 2017, 8, 7710-7721. 
70. Yu, A.; Zhao, L.; Kang, Q.; Li, J.; Chen, K.; Fu, H. Transcription factor HIF1alpha promotes proliferation, migration, and invasion of cholangiocarcinoma via long noncoding RNA H19/microRNA-612/Bcl-2 axis. Transl. Res. 2020, 224, 26-39. [CrossRef]

71. Kwon, H.C.; Kim, S.H.; Oh, S.Y.; Lee, S.; Lee, J.H.; Choi, H.J.; Park, K.J.; Roh, M.S.; Kim, S.G.; Kim, H.J.; et al. Clinical significance of preoperative neutrophil-lymphocyte versus platelet-lymphocyte ratio in patients with operable colorectal cancer. Biomarkers 2012, 17, 216-222. [CrossRef] [PubMed]

72. Wang, D.; Wu, M.; Feng, F.Z.; Huang, H.F.; Ynag, J.X.; Shen, K.; Xiang, Y. Pretreatment neutrophil-to-lymphocyte and platelet-tolymphocyte ratios do not predict survival in patients with cervical cancer treated with neoadjuvant chemotherapy and radical hysterectomy. Chin. Med. J. 2013, 126, 1464-1468. [PubMed]

73. Saeed, A.; Park, R.; Al-Jumayli, M.; Al-Rajabi, R.; Sun, W. Biologics, immunotherapy, and future directions in the treatment of advanced cholangiocarcinoma. Clin. Colorectal. Cancer 2019, 18, 81-90. [CrossRef] [PubMed]

74. Yuan, Y. Spatial heterogeneity in the tumor microenvironment. Cold Spring Harb. Perspect. Med. 2016, 6, a026583. [CrossRef]

75. Bai, R.; Lv, Z.; Xu, D.; Cui, J. Predictive biomarkers for cancer immunotherapy with immune checkpoint inhibitors. Biomark Res. 2020, 8, 34. [CrossRef] [PubMed]

76. Zhang, N.; Jiang, J.; Tang, S.; Sun, G. Predictive value of neutrophil-lymphocyte ratio and platelet-lymphocyte ratio in non-small cell lung cancer patients treated with immune checkpoint inhibitors: A meta-analysis. Int. Immunopharmacol. 2020, 85, 106677. [CrossRef]

77. Xu, H.; He, A.; Liu, A.; Tong, W.; Cao, D. Evaluation of the prognostic role of platelet-lymphocyte ratio in cancer patients treated with immune checkpoint inhibitors: A systematic review and meta-analysis. Int. Immunopharmacol. 2019, 77, 105957. [CrossRef]

78. Diem, S.; Schmid, S.; Krapf, M.; Flatz, L.; Born, D.; Jochum, W.; Templeton, A.J.; Fruh, M. Neutrophil-to-lymphocyte ratio (NLR) and platelet-to-lymphocyte ratio (PLR) as prognostic markers in patients with non-small cell lung cancer (NSCLC) treated with nivolumab. Lung. Cancer 2017, 111, 176-181. [CrossRef]

79. Zer, A.; Sung, M.R.; Walia, P.; Khoja, L.; Maganti, M.; Labbe, C.; Shepherd, F.A.; Bradbury, P.A.; Feld, R.; Liu, G.; et al. Correlation of neutrophil to lymphocyte ratio and absolute neutrophil count with outcomes with PD-1 axis inhibitors in patients with advanced non-small-cell lung cancer. Clin. Lung. Cancer 2018, 19, 426-434.e1. [CrossRef] 